\title{
EVALUATION OF THE PROPAGATION TIME OF A THEORETHICAL FLOOD WAVE IN THE CASE OF THE BREAKING OF CATAMARASTI DAM, BOTOSANI (ROMANIA)
}

DOI: http://dx.doi.org/10.18509/GBP.2018.54

UDC: 627.8:[627.516:528.47(498)

\author{
Liviu-Marian Albu ${ }^{1}$ \\ Andrei Enea ${ }^{1,2}$ \\ Cristian-Constantin Stoleriu ${ }^{1}$ \\ Iosub Marina ${ }^{1,2}$ \\ Gheorghe Romanescu ${ }^{1}$ \\ Hutanu Elena ${ }^{1}$ \\ ${ }^{1}$ Alexandru Ioan Cuza University of Iasi, Faculty of Geography and Geology, Department of \\ Geography, Bd. Carol I 20A, 700505, Iasi, Romania \\ ${ }^{2}$ Integrated Center of Environmental Science Studies in the North Eastern Region-CERNESIM, \\ 11 Carol I, 700506, Alexandru Ioan Cuza University of Iasi, Romania
}

\begin{abstract}
Storage lakes represent an important source of water for the areas with a high deficit of hydrologic balance (ex: Moldavian Plain from NE of Romania). This region holds an important number of lakes that allow the storage of water during periods with rainfall shortage. At the same time, they play an important role in the protection of localities against floods. In addition to the benefits that these lakes have, they can also represent a risk factor for the localities situated in the downstream region, in case of dam collapse. In Romania it is widely known the catastrophic event from 1991 when Belci Dam situated on Tazlău River was breached, causing an entire neighborhood from Onesti City to be flooded. The present study focuses on Catamarasti Lake which has a maximum water volume of 12 million cubic meters, the dam being located $3 \mathrm{~km}$ upstream of the first locality and the periphery of Botosani City. The proximity of the inhabited areas makes the dam break scenario to be a probable event, therefore the identification of the propagation time of a possible flood wave is essential towards the creation of a system for the protection of the population. The dam break simulation and the quantification of the propagation time of the entire water volume on Sitna river valley is made using HECRAS, based on a LiDAR digital elevation model, using the 2D simulation method. In this case, having a likely floodable surface as well as the time in which the flood can reach the nearby localities, there were identified the risk exposed households located in the floodplain, in the vicinity of the river.
\end{abstract}

Keywords: dam, HEC-RAS, lake, management, simulation

\section{INTRODUCTION}

The absence of water in certain regions, the very high probability of flooding or the necessity for generating electric power are some of the main reasons which stood at the basis of the human desire to store water in lakes. Anthropic lakes have the capability to bring a multitude of benefits to the nearby population and settlements, but at the same time the existence of these water bodies can represent a great risk for the populations and 
settlements located downstream [1]. This risk exists through the possibility of the dam (behind which the stream water accumulates), to be breached or to break [2]. One of the most recent events of this type, which implied a dam being exposed to breaking, was the event from February, 2017, at Oroville Lake from California, USA, when a number of approximately 188000 persons were evacuated. This particular event was one fortunate scenario, because no casualties were recorded [3].

In contrast, perhaps the biggest disaster of this kind was the one that took place in China, when the Banqiao and Shimantan dams breached in 1975, causing the loss of over 171,000 human lives, 26,000 from flooding and the other 145,000 from famine and waterrelated disease [4]. Until present, a number of over 2000 dam breaks that had different impacts on society have been recorded, and most of the events of this kind were registered between 1900 and 2000, when the construction of dams has seen an acceleration, due to the ever-increasing need of such hydrostructures [1], [2]. In Romania, a single hydrotechnical accident of high amplitude was registered, in July 1991, when the Belci Dam, constructed on Tazlau river, breached [5]. Other similar events took place during the 2000s, when two dams from the mining area of Maramures County breached, the lakes discharging a volume of approximately $200,000 \mathrm{~m}^{3}$ of cyanide, and contaminated water and 40,000 tons of tailings in the tributaries of Tisa river, representing an unprecedented ecological disaster for Romania and the neighboring countries [6].

At a global scale, earth dams are the most frequent, having higher probabilities of breaching than other types of dams. The most common reasons for the failure of earth dams are overtopping and piping [1], [2]. In Romania, there are a few thousands of lakes and ponds, with a volume of water that is held by an earth dam and in case of a dam breach, the highest damage is associated to the lakes with high water volumes, discharged after a dam failure [7]. The Romanian Register of Big Dams contains a list of dams which are already built (containing a number of 246 dams, from which 84 are earth dams, 96 are earth dams or gravity dams, 5 are mobile dams and earth dams, others being of different type), or in construction, mentioning that the height of the dam is greater or equal to 10 meters, or the volume is greater or equal to 1 million $\mathrm{m}^{3}$ [8].

The high number of earth dam lakes in Romania and the recent hydrotechnical accidents led to the need of a case study involving an earth dam of high dimensions, namely Catamarasti Dam, built in 1979 on Sitna River, upstream of the metropolitan area of Botosani City, putting at risk an important number of people from the vicinity. The analysis which was carried out was a 2D unsteady flow modelling, using HEC-RAS 5.0.3 for a theoretical breach, that can appear in the earth dam, thus evaluating the impact that a dam break generated flood can have on the inhabited area, located downstream of this reservoir.

\section{STUDY AREA}

The study area is defined by Sitna river valley, downstream of Catamarasti dam, on an approximate length of $6 \mathrm{~km}$. Catamarasti Lake is part of Sitna river basin, a right-side tributary of Prut River, which is located in the North-Eastern part of Romania, occupying an area in the Central and Southern part of Botosani County. Sitna river basin occupies an area of $943 \mathrm{~km}^{2}$, the river stretching for a length of $78 \mathrm{~km}$, with an average flow rate of $2,16 \mathrm{~m}^{3} / \mathrm{s}$. Catamarasti Lake is placed on Sitna river, on the administrative area of Mihai Eminescu commune, in the upper part of the basin, at an approximate distance of $3 \mathrm{~km}$ North of Botosani City (Fig. 1). 
The lake is an artificial waterbody with a non-rock/gravel padded type of bottom, a length of $2.6 \mathrm{~km}$ and a surface of 160 hectares, with a homogenous earth dam and clay sealing, a height of 15 meters, and a length of 540 meters, being constructed in the year of 1979 . The spillway of the dam is composed of two parts: a spillway with free discharge at the top, and a system of penstocks at the bottom. The spillway discharge is of $154 \mathrm{~m}^{3} / \mathrm{s}$. The main purpose of the lake is mainly for irrigation, fish farming and flood attenuation [8], [9].

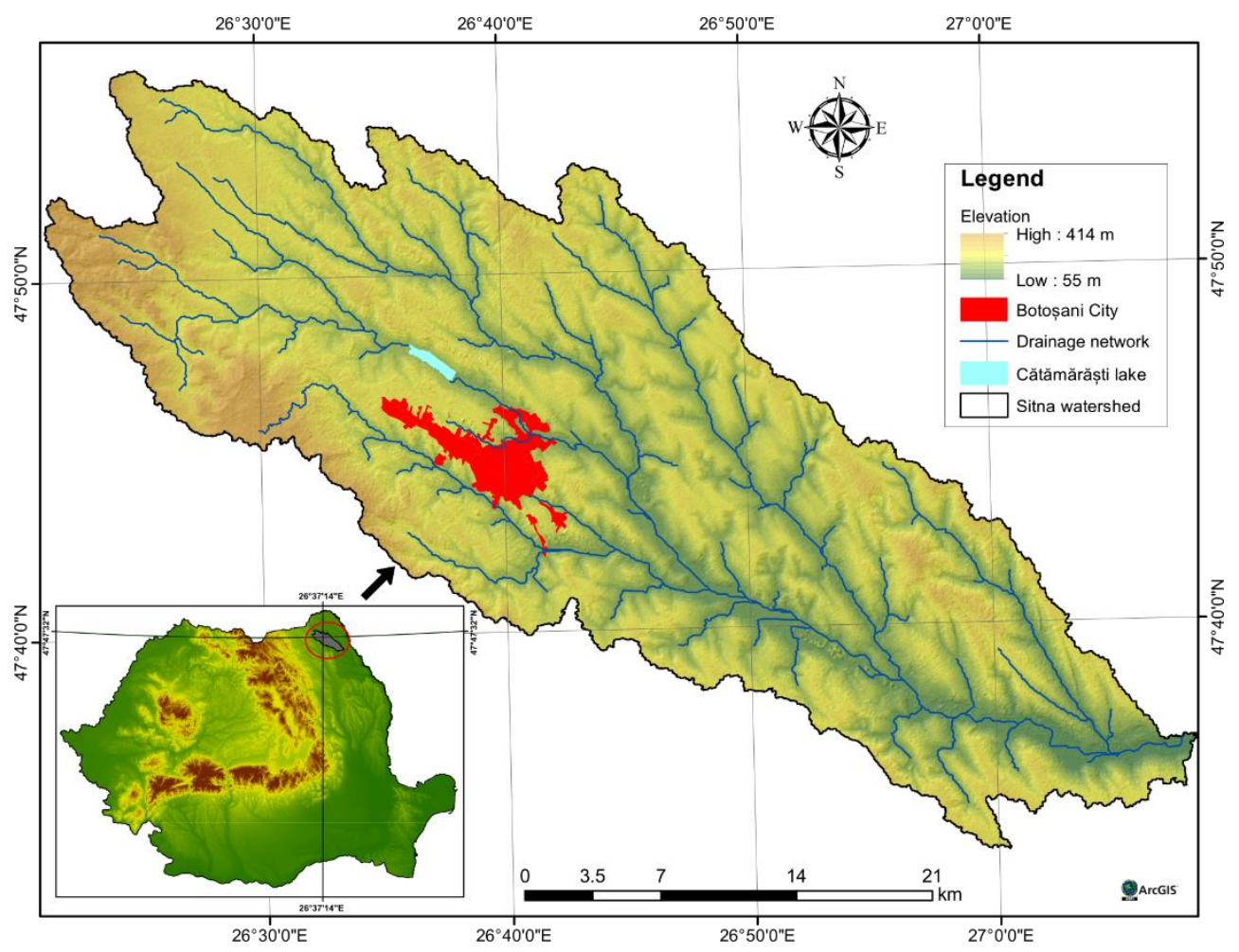

Figure 1. Geographical location of Catamarasti Lake in Sitna watershed

The region where the attention was focused on is represented by Sitna river valley downstream of Catamarasti Dam, an area mostly used for pastures and agricultural land. Because the dam is at 3 kilometers upstream of Botosani periphery and other settlements, and the river is very close to these inhabited areas, the potential damages caused by a sudden dam break, would be catastrophic.

\section{METHODOLOGY}

In order to run the dam break simulation, a numerical terrain model that replicates to a very high fidelity the in-field reality, had to be used. For the purpose of obtaining a highquality modelling, the most suitable terrain data that could be used was in the form of LiDAR Digital Elevation Model, at a spatial resolution of 1 meter [10]. Before any geometry data could be generated, the data was first converted into Hierarchical Data Format (hdf) and imported into HEC-RAS environment. For the dam break analysis, geometric data and water volume of the lake were required. The first phase of the analysis consists in defining the geometry layers for the area of study. This step implied the digitization of the lake, using the Storage Area option, and the use of 2D Flow Area to 
define the downstream area (Fig. 2), where the output from the dam breach will be simulated [11].

The mesh generated by the 2D Flow Area option acts similarly to the cross-sections used mostly in 1D simulations, with the difference that this option can better use the elevation of the DEM by modifying the computation cell spacing, which implies the changing in size of the mesh cells. Due to the highly unsteady nature of the dam break flood, low sized cells were considered. Some additional corrections needed to be done in the mesh, to eliminate some imperfections, like adding additional points where is needed and removing some points for the mesh, to be correctly used in the analysis. Concerning the input data for the storage area, the maximum volume of water which the lake can hold was considered for the simulation, namely 12 million $\mathrm{m}^{3}$.

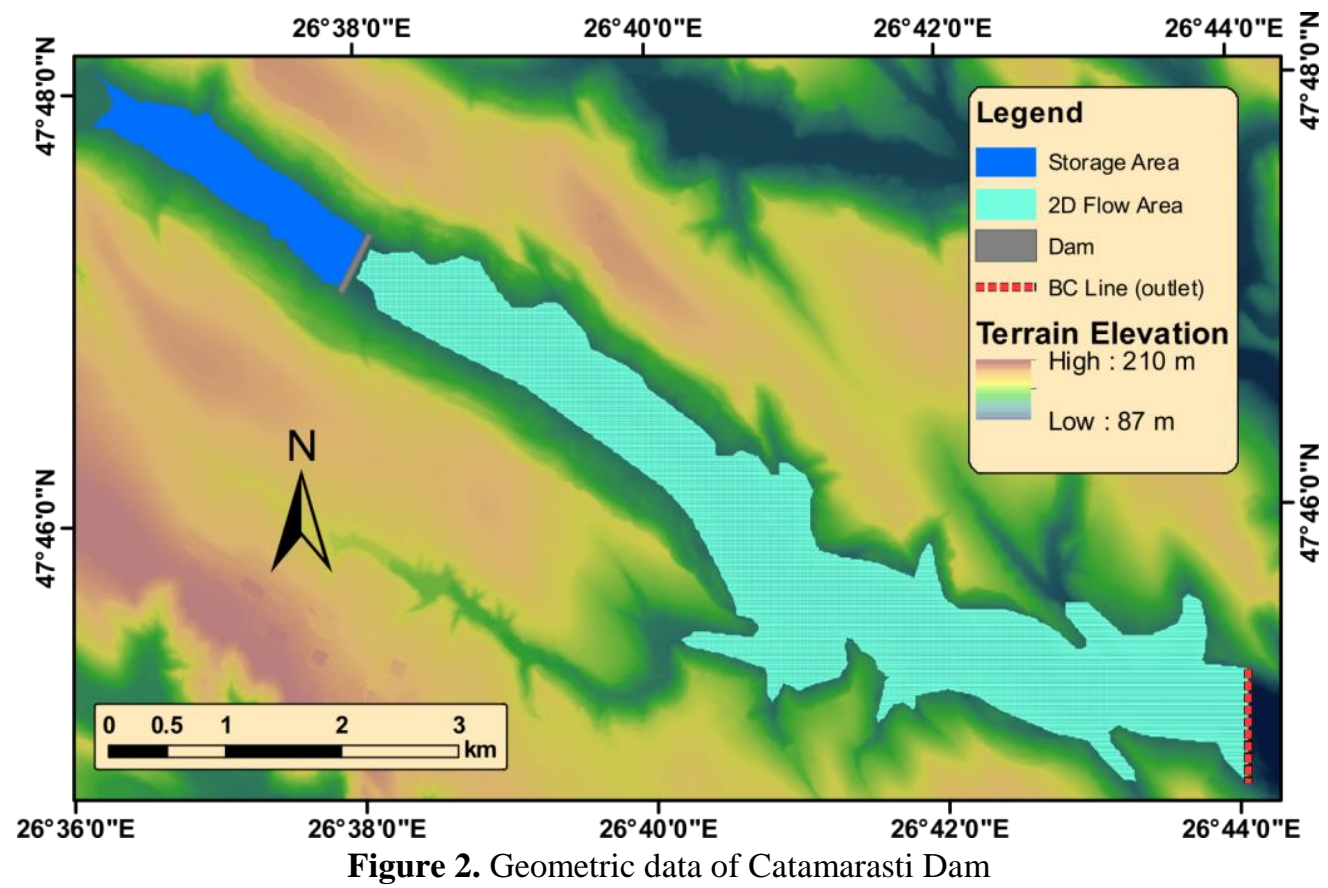

As a final element of the geometric input to the dam break model, to specify the dam and the physical characteristics of it, the option SA/2D Area Conn was used, modelling the dam as a weir. This option also allowed for the upstream and downstream geometric data to be connected through the modelled dam. To be able to model a dam breach in HECRAS, failure mode, breach size and breach time needed to be entered. After the dam was digitally reconstructed, the breach parameters were inserted into the breach plan data, selecting the overtopping failure mode of the dam and 30 minutes time for the breach to form [11]. The shape of the breach was assumed to have a rectangular form.

The assumptions regarding the boundary conditions, as a part of the analysis, are also critical, as far as dam break modelling is concerned, as they could directly affect the extend of downstream flood water. These boundary conditions need to be properly selected and, at the same time, to be able to accurately represent the site conditions. In a more complex analysis, detailed hydrologic data is needed to be able to model a more realistic scenario of a dam break flood, like inflow data [12]. In this study, the boundary conditions which were taken into account were: Elevation-Volume data (to represent the storage upstream of the dam), and Normal Depth (for the downstream boundary conditions). 
For the dam break flood simulation, Manning values of 0.06 for the floodplain were used, considering the fact that the area downstream of Catamarasti dam is covered by pastures and agricultural land. These values were selected based both on generalized reviewing of the land use situation and aerial imagery of the area. Based on the geometric and boundary conditions data, the dam break simulation was run, for a time period of 12 hours, choosing a computation interval of 10 seconds and a mapping interval of 1 minute, for the dambreak flood model to be more stable [11].

\section{RESULTS AND DISCUSSIONS}

The primary pursuit of this analysis was identifying the propagation time of a dam-break generated flood wave, which is essential for the development of human protection systems, and ultimately, for warning the authorities and population downstream of the dam, for proper and rapid measures to be taken in case of imminent disaster. Due to the placement of the dam in the vicinity of Botosani City and other localities, the analysis was made by considering the worst-case scenario, namely the failure of Catamarasti dam at full capacity, that of 12 million $\mathrm{m}^{3}$ of water volume.

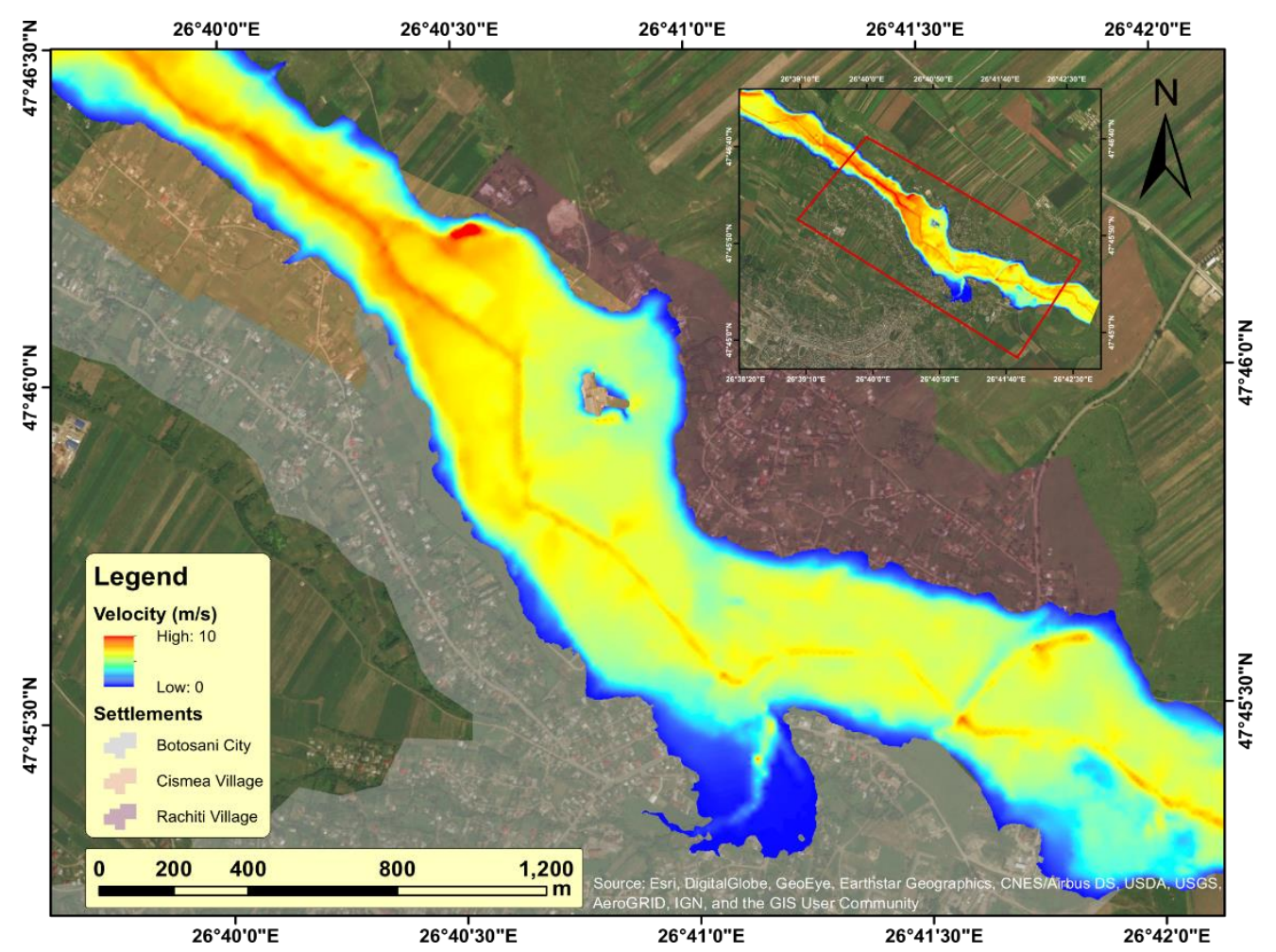

Figure 3. Velocity of the generated dam-break flood water in the areas of Cismea and Rachiti Villages and Botosani City periphery

The final products of the unsteady analysis carried out in HEC-RAS 2D module represent a series of maps showing the velocity of the flood water in the affected areas and the overlay of the dam-break generated flood on top of the affected areas. The cartographic materials were created using ArcGIS. The first result (Fig. 3) shows the velocity of the water in the flooded areas, in Cismea and Rachiti villages and across the northern side of Botosani City periphery. After the dam was teoretically breached, the resulted flood wave arrived, first in Cismea village, in approximately 40 minutes, entering the village with a 
speed of $6 \mathrm{~m} / \mathrm{s}$. Starting from this point, the velocity of the water started to drop, recording maximum flow speeds of $4.8 \mathrm{~m} / \mathrm{s}$ in Botosani City periphery, entering the city with speeds of $4.2 \mathrm{~m} / \mathrm{s}$, rapidly decreasing towards small values and $4 \mathrm{~m} / \mathrm{s}$ in the affected areas from Rachiti village, the velocity continuing to drop towards downstream, exiting the urban area of Botosani City, with simulated flow speeds at a maximum of $4.4 \mathrm{~m} / \mathrm{s}$.

Concerning the damages generated by the flood, a map showing the potentially damaged constructions and households across the affected areas was made (Fig. 4). The total number of households and building damaged by the generated flood is 336 , with a number of 82 households damaged in Cismea Village, a total of 125 households in Rachiti Village, and 129 affected households in Botosani City. The counted households and buildings which were affected may not seem that high, but considering the city and nearby villages, and in the case of a broader damage analysis, the affected objectives would include other elements, like streets, bridges, the economic purpose of the buildings, etc. For this analysis, the variable chosen to highlight the magnitude of this scenario was the number of affected buildings and constructions.

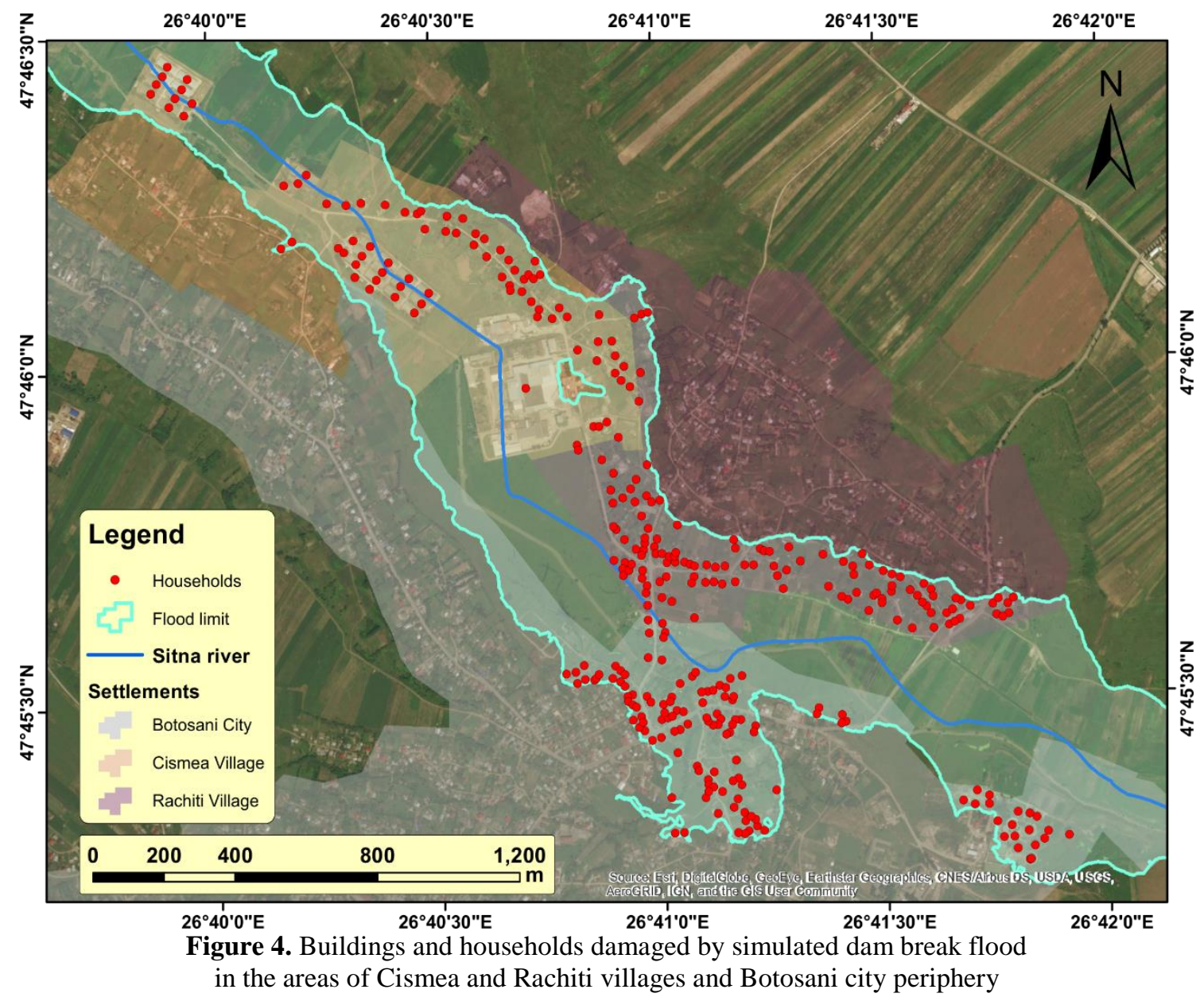

As a final cartographic product of the dam break analysis, a map with the flood water depths was generated, as it can be seen below in Fig. 5. As it can be observed, the values of the flood water depth are spanning in a range between 0.001 meters, to 14.755 meters, the generated values dropping on an upstream-downstream direction and also towards the side limits of the flood. The maximum depth of the water is located at the entrance into the inhabited area, concentrated mainly in the middle region of the flooded area, where 
Sitna River flows. Because the river valley widens towards downstream, implicitly, the flood extends, it covers larger portions of land and inhabited zones, the most affected parts being the periphery of Botosani City, where the depth values are the highest, covering the largest portions among the three inhabited areas.

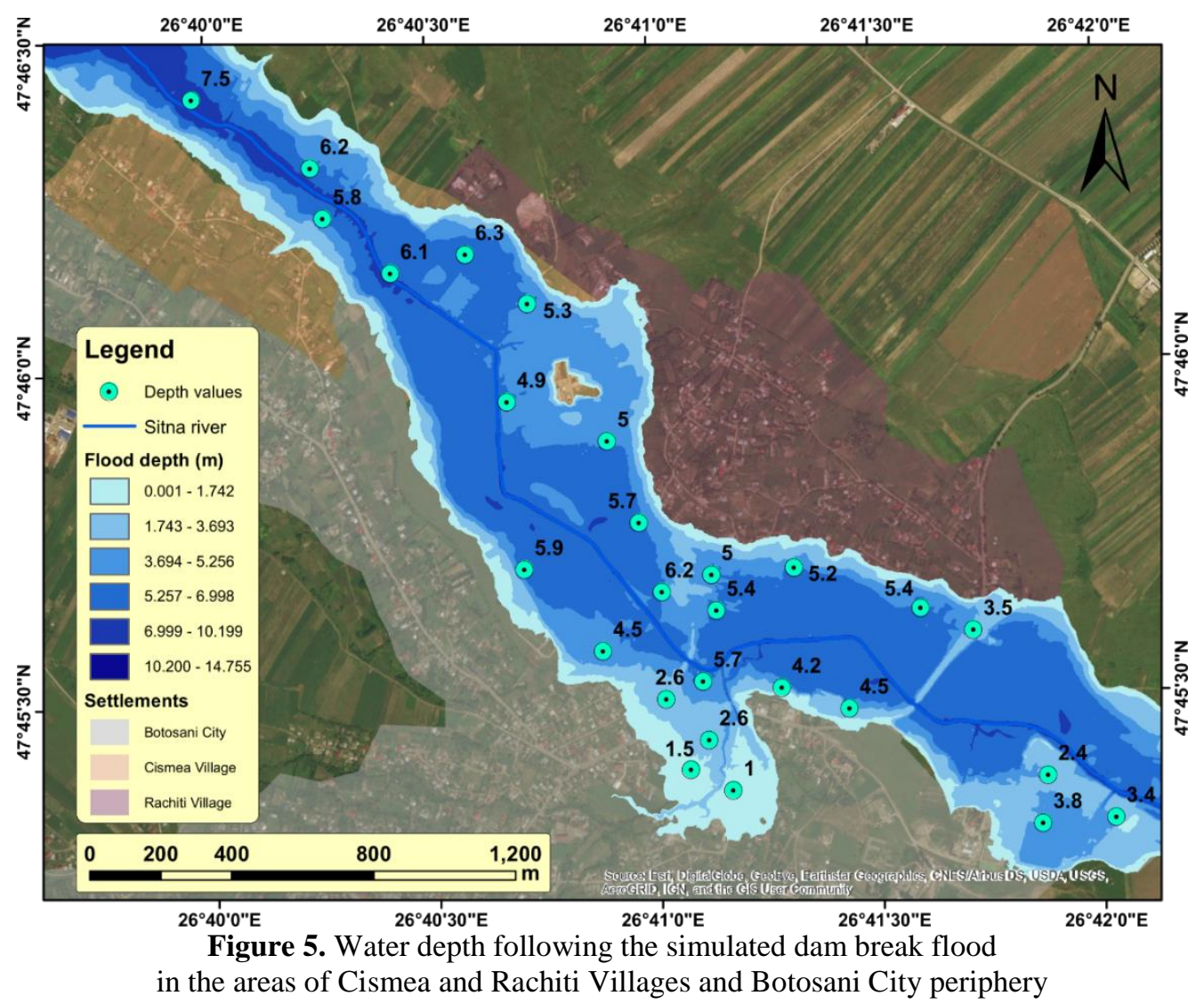

The total area covered by the generated flood in the inhabited areas, counts a surface of 195.026 hectares. Regarding the area covered for each of the villages with the simulated water, the flooded surface in Cismea village counts 47.44 hectares, 30.49 hectares in Rachiti village, and 46.75 hectares in Botosani City. Overall, the dam break analysis revealed that, in case of such an event, a large portion of land can be affected by floods, involving a high number of affected households, with high velocities and depths, which would represent an important argument for the authorities towards the development of a protection system, and warning for the vulnerable population located downstream, in case such scenario would actually manifest in the future.

\section{CONCLUSIONS}

Dam break analysis is a complex process, requiring intensive study for a good understanding of how the mechanisms related to computer simulations function. For a reliable analysis, accurate elevation and hydrological data are needed. Concerning the methodology of simulating a dam-break flood, the 2D module of HEC-RAS 5.0.3 proved to be a suitable environment for this analysis, having multiple options for detailed and complex flood studies.

The study area chosen for this exercise was relevant, due to the proximity of settlements to an earth dam, which could potentially represent a risk for the population living 
downstream, in case of dam failure. The results were significant, offering detailed insight to the potential outcome of a hydrological event of this kind, and at the same time, underlying the importance of developing a safety plan for the exposed population. By taking into account the results of the present study, the authorities could use the findings, for the development of an efficient strategy, regarding the warning of the population in case of disaster and for better managing of the potential damages caused by a dam break scenario.

\section{ACKNOWLEDGEMENT}

This work was financially supported by the Department of Geography from the "Alexandru Ioan Cuza" University, of Iasi, and the infrastructure was provided through the POSCCE-O 2.2.1, SMIS-CSNR 13984-901, No. 257/28.09.2010 Project, CERNESIM.

\section{REFERENCES}

[1] Singh V. Dam breach modeling technology, Springer Science + Business Media, pp. 255, 1996.

[2] Zhang L., Peng M., Chang D. \& Xu Y. Dam Failure Mechanisms and Risk Assessment, Wiley, Singapore, pp. 499, 2016.

[3] Stork R., Shutes C., Reedy G., Schneider K., Steindorf D. \& Wesselman E. The Oroville Dam 2017 Spillway Incident and Lessons from the Feather River Basin, California Hydropower Reform Coalition, pp. 60, 2017.

[4] Xu Y., Zhang L. \& Jinsheng J. Lessons from Catastrophic Dam Failures in August 1975 in Zhumandian, China, GeoCongress 2008 - Geosustainability And Geohazard Mitigation, New Orleans, Louisiana, United States, pp. $162-169$.

[5] Enea A. Metode si tehnici moderne de cuantificare a vulnerabilitatii la inundatii in bazinul hidrografic Tazlau, PhD Thesis, Alexandru Ioan Cuza University, pp. 192, 2017.

[6] Macklin M., Brewer P., Balteanu D., Coulthard T., Driga B., Howard A. \& Zaharia S. The long-term fate and environmental significance of contaminant metals released by the January and March 2000 mining tailings dam failures in Maramureș County, upper Tisa Basin, Romania, Applied Geochemistry, Elsevier, vol. 18, no. 2, pp. 241-257, 2003.

[7] Romanescu, G., Romanescu, A.M. \& Romanescu, Gabriela. History of Building the Main Dams and Reservoirs, In: Proceedings of the 2nd International Conference on Water resources and wetlands, Tulcea, Romania, pp. 11-13, 2014.

[8] The Romanian Register of Big Dams - http://www.baraje.ro/rrmb/rrmb_idx.htm (accesed 14.02.2018)

[9] Vieru D.N. \& Vieru N.P. The evaluation of the risk for floodings on the territory of Botosani municipal town. GEOREVIEW: Scientific Annals of Stefan cel Mare University of Suceava, Geography Series, vol. 19, no. 1, pp. 81-90, 2010.

[10] Raber G.T., Jensen J.R., Hodgson M.E., Tullis J.A., Davis B.A. \& Berglund J. Impact of LiDAR nominal post-spacing on DEM accuracy and flood zone delineation, Photogrammetric engineering \& remote sensing, vol. 73, no. 7, pp. 793-804, 2007.

[11] US Army Corps of Engineers. Hydrologic Engineering Center, HEC-RAS River Analysis. User's Manual, pp. 960, 2016.

[12] Xiong, Y. A dam break analysis using HEC-RAS. Journal of Water Resource and Protection, vol. 3, no. 6, pp. 370-379, 2011. 